\title{
Management Control System Of State Transport Undertaking- An Analysis Of Haryana Roadways
}

\author{
Ms. Seema Jain \\ Department of Management \& Humanities \\ Sant Longowal Institute of Engineering \& Technology, \\ Longowal Punjab 148106(INDIA) \\ Dr. Pawan Kumar Dhiman \\ Department of Management \& Humanities \\ Sant Longowal Institute of Engineering \& Technology, \\ Longowal Punjab 148106(INDIA)
}

\begin{abstract}
Since centuries for overall development of nation and human civilization transport had played a vital role and changed the way of life of the human being. Public transport is to provide people with mobility and access to employment, education, retail, health and recreational facilities, as well as community facilities. The primary objective of Public transport is to provide public service. The infrastructural development and inter connecting villages with cities, lifting the goods and providing services to the people to visit one place to another transport have proved a boom in the economy. The more trips that are made by public transport reduces the number of trips that are made by private vehicles, leading to less congestion on the roads and a more efficient road system. The present paper studies Haryana State Road transport Undertaking as an organization from the aspect of control system and their effectiveness. For the goal consonance of this study Simon's four levers of control model applied.
\end{abstract}

Keywords: State Road Transport, Haryana Roadways, Management, Control System.

\section{INTRODUCTION}

A country cannot progress economically unless it has a good system of transport which links its different parts together and also different parts of the world. The progress in agriculture to industry depends upon number of factors start with farmers to obtain the necessary seeds for farming, fertilizers, farm machinery, etc. whereas on the other hand and find the market for crops and the disposal of produced products from the industry. Today, the road transport system has become a buzzword, fundamental necessity and functions in an exceptionally flexible and diversified manner. It provides linkages to the other modes such as railways, airports, ports and linking these modes in fulfilling the transportation needs of the public. After independence keeping in mind topography of the country almost in all the states one state transport undertakings has been established with different names. The state of Haryana is a rich state and economically strong and industrially advanced. Table- 1 explains that the Gross state value added and Gross state Domestic Products, Services and industrial output is more as compared to all India level. 
Table 1- Growth in Gross State Value Added at constant (2011-12) prices.

\begin{tabular}{|c|c|c|c|c|c|}
\hline \multirow[t]{2}{*}{ Sector } & \multicolumn{4}{|c|}{ Haryana } & \multirow{2}{*}{$\begin{array}{l}\text { All India } \\
\text { 2016-17 (A) }\end{array}$} \\
\hline & 2013-14 (P) & 2014-15 (P & 2015-16 (Q) & 2016-17 (A) & \\
\hline $\begin{array}{l}\text { Agriculture \& } \\
\text { Allied }\end{array}$ & 2.8 & -1.9 & 2.9 & 6.4 & 4.1 \\
\hline Industry & 7.4 & 2.2 & 7.9 & 6.4 & 5.2 \\
\hline Services & 9.9 & 10.3 & 10.9 & 10.8 & 8.8 \\
\hline GSVA & 7.6 & 5.2 & 8.4 & 8.6 & 7.0 \\
\hline GSDP & 8.2 & 5.7 & 9.0 & 8.7 & 7.1 \\
\hline
\end{tabular}

P: Provisional Estimates, Q: Quick Estimates, A: Advance Estimates

Source: Department of Economic and Statistical Analysis, Haryana.

The transport department in Haryana having two wings i.e. the Regulatory wing and commercial wing (Haryana Roadways). The regulatory wing has been entrusted with the responsibility of the implementation of provisions of the Motor Vehicle Act, 1988, Central Motor Vehicles rules 1989, Carriage by Road Act, 2007, Carriage by Road rules, 2011, Haryana Motor Vehicles rules, 1993, Haryana Motor Vehicles Taxation Act, 2016, Haryana Motor Vehicles Taxation rules, 2016.

Under the commercial wing, Haryana Roadways State Transport Undertaking (HRSRTU) a State Government Undertaking is the principal service provider for passenger transport in the State. When Haryana was carved out of Punjab there arouses a need of separate transport unit which would connect every part of the state with other parts effectively. State Transport (HR) was founded in 1966 as Public Sector Corporation under the Ministry of Transport of the Government of Haryana. On 1 December 1987, three RTAs were appointed at Ambala, Hisar and Faridabad. On 16 January 1991, three more RTAs were created at Rohtak, Karnal and Rewari. Now, each district headquarters has Regional Transport Office (RTO) headed by Regional Transport Secretary and vehicle registration and driving licenses can be obtained from each district headquarters (RTA office) and Tehsil headquarters.

Haryana Roadways has 24 depots, each headed by a General Manager, and 13 sub-depots functioning under the depot concerned and a fleet of about 4250 buses. These services are being provided to every part of the State as well as to important destinations in the neighbouring States. Haryana Roadways covered $1.2 \mathrm{Km}$ approx. and carry an average of 10.87 lakh passengers every day. Over the years Haryana Roadways has earned a name as a quality service provider. To provide better service Haryana Roadways has started new Volvo AC bus services 'Saarthi' on particular routes included also the Indira Gandhi International (IGI) Airport and the domestic Airport Delhi. In addition Haryana Roadways provide deluxe bus service (2x2 seats, FM Radio, Mobile charger, Pneumatically operated door, Tinted glass and curtains etc.) at normal rate of fare that is known as 'Aam Adami Ki Khas Bus'.

\section{LITERATURE REVIEW}

Control is concerned with blend of regulating, directing, restraining activities performed by units and subunits of the organization. It is the way to ensure that the work which is under process as per the desired state of affairs. It is the system to verify that the activities and endeavor are producing only objective and goals oriented results (Ghosh, 2005). Strategy formulation that involves goals, strategies and policies create the base of management control under which manager influence the employees of the organization for strategic implementation. Strategic implementation mechanism perform as a unifying interrelated action of management control, human resource management, culture and organizational structure for that strategy is a input to accelerate the performance (Anthony, Govindranjan, 
2008). Continuous maintenance and control act as pillar to achieve continuous benefits from a process oriented organization which may lead to overcome coordination problems exists in functional units which may result long process cycle, low quality of product and repetition task. Workflow based controlling system is also helpful to measure the operational performance of any organizational process (Muehlen, 2002). Success of any process or project depends upon the completion of any activity within allocated time period and budgeted cost (Kerzner, 2001). TQM (Total Quality Management) and BPR(Business Process Reengineering) are examples of recent management control system innovations that change the organization culture and promote continuous improvement of products and services (Sisaye, 2006).

\section{STATEMENT OF THE PROBLEM}

Management control of transport comprises strategic management, human resource management, fleet management, fuel costing, routing and mapping even accounting. Control implies a good integration among all the sectors and sub sectors of organization to achieve the desired state of affairs that can be physical or financial. Transport has become a base parameter of development as like technological advancement. Due to increasing competition, changing customer behavior and demand specification it becomes necessary to maintain a system of effective control system and identify its weakness and strengths.

\section{OBJECTIVE OF THE STUDY}

The aim of the research is to analyse the management control system, effectiveness of SRTU (Haryana) outcomes in profitability and focus on the gaps in the control system of HRSRTU.

\section{SIGNIFICANCE OF THE STUDY}

The effective control system is the life wire of any organization that can improve its financial and physical health to a great extent. The need for this study, therefore, finds the gaps in strategic implementation and on that basis the recommendation that were made at the end of the study.

\section{RESEARCH METHODOLOGY}

The present research is descriptive in nature and has been studied by using secondary data. Haryana State is one of the developing states that come forward as a centre of education and excellence. The state is bound by Uttar Pradesh in the east, Punjab in the west, Himachal Pradesh in the north and Rajasthan in the south. It is the $16^{\text {th }}$ largest state in the country with an area of 44212 square kilometer. It has the third highest per capita income in the county after the capital Delhi and state of Goa.

\section{ORGANIZATIONAL STRUCTURE OF SRTU OF HARYANA}

Haryana Roadways a state government undertaking working with the prime objective to provide adequate, comfortable. Economical, reliable, efficient, safe and environment- friendly modern passenger transport services for the public.Road Transport headed and controled by Transport Minister who is responsible to formulate Policies, sponsor and support programmes, provide funding assistance to state and city governments, set up standards and guidelines, ensure coordination between relevant stakeholders including lower levels of government, appraise progress of programmes and ensure successful implementation through timely monitoring. Haryana Roadways being a limited company the Principal Secretary, Govt. of Haryana, Transport Department holds the post of Chairman of this Corporation and Director General of State Transport, Haryana holds the post of Managing Director. This Department is headed by a Director General with Head Office at Chandigarh who is assisted by Additional Transport Commissioner, Joint State Transport Commissioner and Deputy Transport Commissioners. The Director General State Transport is responsible for providing well- 
coordinated, economical, safe and efficient transportation services to the public. The basic unit of this study is the depot as it is the place where the operational performance has done and the actual revenue has been generated.

At the depot level, the General Manager is assisted by Works Manager, Traffic Manager, Store Purchase Officer and other line officers like Accounts Officer, Assistant District Attorney, and Superintendent etc.

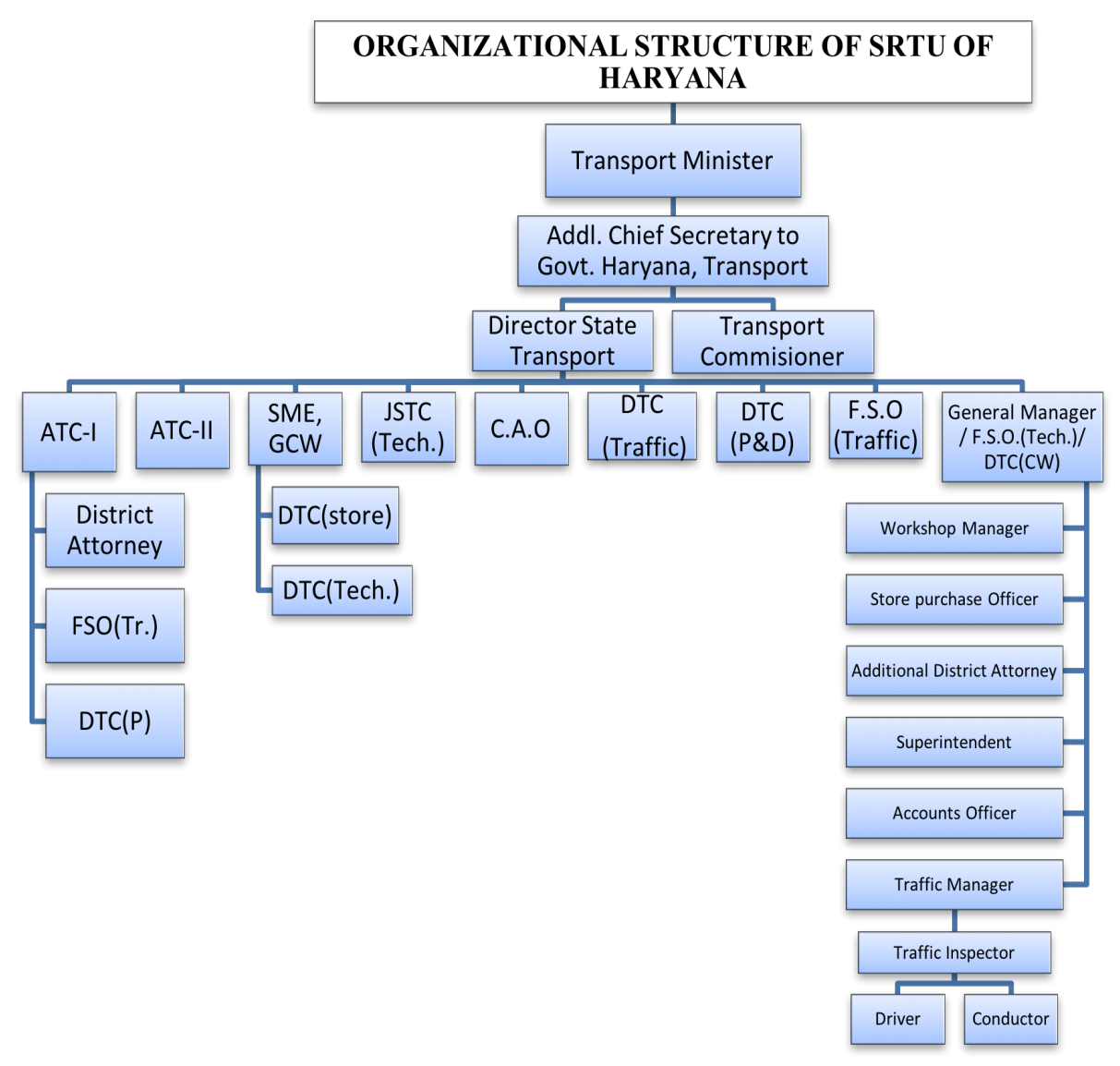

The following stands for:

ATC-l: Additional Transport Commisioner-l ATC-ll: Additional Transport Commisioner-ll SME: Senior Mechanical Engineer JSTC(T): Joint Transport Commisioner(Technical)
CAO: Chief Accounts Officer

DTC: Deputy Transport Controller FSO: Flying Squad Officer 
Table 3 : Duties And Responsibilities Of Depot Employees

\begin{tabular}{|c|c|}
\hline EMPLOYEES DESIGNATION & DUTIES AND RESPONSIBILITIES \\
\hline General Manager & $\begin{array}{l}\text { The Depot is controlled by Depot manager or General Manager who is } \\
\text { responsible for execution of daily administration. He has the authority of } \\
\text { job assignment to the employees working in the depot. Every depot has } \\
\text { some spare buses and extra employees to compensate absent } \\
\text { employees. }\end{array}$ \\
\hline Workshop manager & $\begin{array}{l}\text { The workshop Manager (WM) works under the General Manager and is } \\
\text { responsible for mechanical maintenance of the buses. WM has the } \\
\text { authority to audit the KMPL achieved by the drivers and condition of } \\
\text { damage vehicle and also has the record of off-road fleet that are in } \\
\text { waiting list for repair at depot. He is also responsible to manage and } \\
\text { curtail the bus schedules according to their maintenance as fleet } \\
\text { breakdown, covered kilometers and mechanical repairs. }\end{array}$ \\
\hline Store Purchase officer & $\begin{array}{l}\text { Store Purchase officer has the responsibility to order items as diesel, } \\
\text { spare parts for fleet according to the requirements. He has to identify the } \\
\text { requirements of items at optimum level so that due to shortage of items } \\
\text { buses should not stand off-road at depot. He maintains the consumption } \\
\text { record of items and receipt also. }\end{array}$ \\
\hline Additional District Attorney & $\begin{array}{l}\text { District Attorney or Deputy District Attorney is responsible to look after } \\
\text { the legal matters of the department. }\end{array}$ \\
\hline Superintendent & $\begin{array}{l}\text { They observe employees absenteeism and maintain the record of their } \\
\text { leave, daily administrative and routine activities simultaneously. }\end{array}$ \\
\hline Account Officer & Account Officer at depot issues the ticket and cash receipt also. \\
\hline Traffic Manager & $\begin{array}{l}\text { They look after the traffic operations like plying of various bus services, } \\
\text { route planning, time table of buses, and allotment of routes. They } \\
\text { assisted by traffic inspector. }\end{array}$ \\
\hline Traffic Inspector & $\begin{array}{l}\text { He supervises drivers and conductors and allocates the duties to them. } \\
\text { He maintains the record of their attendance, leaves, KMPL etc. He } \\
\text { prepares the route according to depot target of routes, kilometers and } \\
\text { earning targets. }\end{array}$ \\
\hline Drivers & $\begin{array}{l}\text { They are responsible safe and timely arrival of bus as per the schedule } \\
\text { timings. They have the target of KMPL (kilometer per litre of diesel) to } \\
\text { achieve through diesel consumption. They are also accountable to } \\
\text { maintain the condition of vehicle, minimum damage from accidents. }\end{array}$ \\
\hline Conductors & $\begin{array}{l}\text { The performance of conductors assessed by total receipts generated } \\
\text { from ticket collection. The amount of expected revenue had already fixed } \\
\text { for every schedule as target based on experiments and pilot survey. If } \\
\text { any conductor was unable to achieve target revenue then he would be } \\
\text { warned or penalized by traffic inspector. } \\
\text { Duty schedule and reporting time of driver and conductor has already } \\
\text { mentioned as written instruction must be followed by both. The } \\
\text { performance of drivers and conductors was assessed by their behavior } \\
\text { with the passenger also as the basic service quality parameter. } \\
\text { Employees were rewarded by appraisal letter if they perform good and } \\
\text { achieve their target such as generate more revenue, fleet maintenance } \\
\text { and effective KMPL etc. }\end{array}$ \\
\hline
\end{tabular}

\section{Management Control system in Haryana Roadways}

To achieve its primary objectives Haryana Roadways has viewed as Four Levers of control to generate profit and work as organizational framework

\section{Core Values and Belief System}

Haryana Roadways is highly customer centric and has undertaken some new facilities for better services to the customers such as Volvo AC bus service known as 'Saarth', Haryana Gaurav bus service called as 'Aam Adami Ki Khas Bus' having deluxe facilities like 2x2 seats, 
pneumatically operated door, FM radio, tinted glasses, mobile charger and curtains etc. at ordinary bus fare. It also facilitates some additional routes including the Indira Gandhi International Airport and domestic Airport. In HRSRTC online reservation facility is available that makes the traveling of passenger easy, time saving, and CNG bus service as 'Haryana Uday' which is most innovative has been launched in the national capital region of Delhi. In addition to it also increasing its services by running 150 low floor buses under JnNURM in Faridabad.

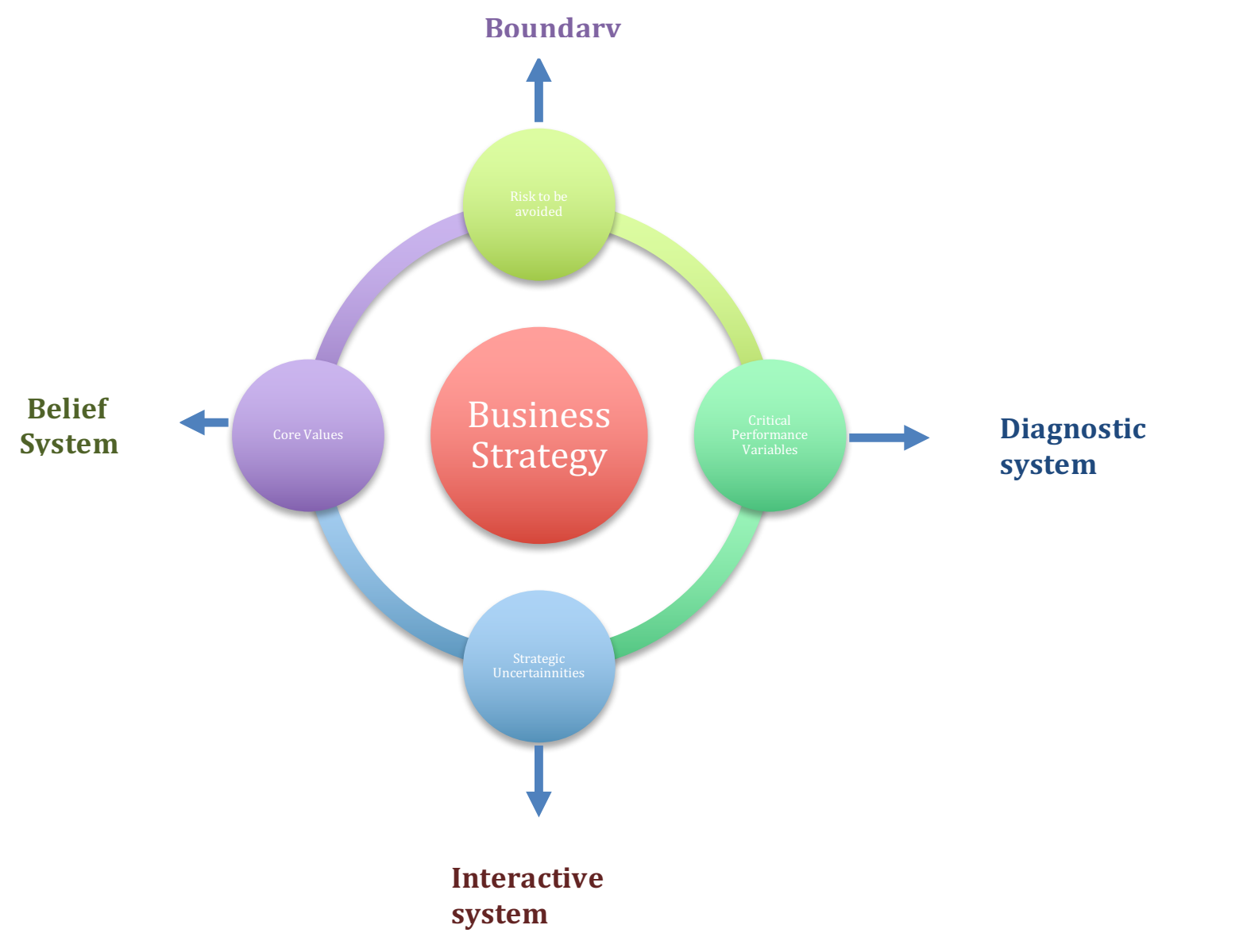

\section{Figure -1: Simon's Four Levers of Control Source: Harvard Business School Press, 1995,}

HRSRTC also releases accident relief fund and having the policy to respond every public complaint. To boost the morale and to increase the efficiency of employees HRSRTC provides training to their employees at every level. Haryana Roadways is running 18 departmental drivers training schools for imparting training for heavy and light vehicles in different locations. For employees HRSRTC provides the facilities of tour in a year and free travelling pass for their family within state.

\section{Boundary System}

In HRSRTC the rules and regulations are well documented and circulated among the employees, alcohol could not be consumed on duty, to behave with passengers in a certain manner. If any employee found disobey or involved in case of any fraud, right action to be taken. To control the corruption every employee has to show the detail of their assets before the purchase and liabilities to the corporation. 


\section{Diagnostic System}

At Depot level, KMPL and EPKM are closely monitored in which base the performance of driver and conductor is measured. Depot manager who has to plans work schedule for forthcoming week and assign the responsibilities to every level of employee before two days. The driver and conductor sign their duties in prior intimation under formal control system. If any employee or conductor is found pilfering he must be penalized accordingly. The central office of HRSRTC is situated in Chandigarh (Haryana) where the detail of all depots of HRSRTC compiled as departure, late departure, breakdown and financial performance in a particular format. If any deviation was there the Director and Managing Director was to be informed. To motivate the employees reward a certificate of good performance is also provided to employees in case of driver and conductor those achieve more KMPL and EPKM respectively

\section{Interactive System}

There were no worker's participation in management but in some particular situation the suggestions are required from employees. The department has set up 100 bus stands at important terminals at Karnal, Bawal, and Ambala city, Gurugram, Faridabad and development has been taken of NIT Faridabad bus terminal on PPP (Public Private Partnership) mode. The drivers are appointed after driving test having minimum 5 years' experience. After some time on regular basis training to drivers are given through under some training programme time to time The workshops are being modernized by providing latest machinery, tools and infrastructure etc. for better up keep of the buses. The department has also introduced an optional e-payment of road tax facility and SMS alert to intimating about payment. To fulfill its social obligations HRSRTU is providing free/ concessional travel facilities to different categories. By implementing all these control mechanism and due to Consistent quality and punctuality of the service provider have HRSRTC has earned a name in all neighbouring state and have become the first Choice of the passengers. But after its growth and other remedies HRSTC is bearing losses the details has been shown in the following table. 
Table 4: Growth rate of Performance of HRSRTU

\begin{tabular}{|c|c|c|c|}
\hline Performance parameter & Year & Figures & Growth rate in \% \\
\hline \multirow{5}{*}{$\begin{array}{l}\text { Average Fleet Held } \\
\text { (Numbers) }\end{array}$} & $2011-12$ & 3402 & ------ \\
\hline & $2012-13$ & 3755 & 10.38 \\
\hline & 2013-14 & 3816 & 1.62 \\
\hline & $2014-15$ & 4083 & 7.00 \\
\hline & $2015-16$ & 4170 & 2.13 \\
\hline \multirow{5}{*}{$\begin{array}{l}\text { Average Age of Fleet } \\
\text { (Years) }\end{array}$} & $2011-12$ & 7.0 & 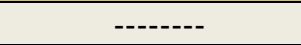 \\
\hline & $2012-13$ & 3.1 & -55.71 \\
\hline & $2013-14$ & 3.1 & 0.00 \\
\hline & 2014-15 & 3.36 & 8.39 \\
\hline & $2015-16$ & 4.07 & 21.13 \\
\hline \multirow[t]{5}{*}{ Over- aged Vehicles \% } & 2011-12 & 3.0 & -------- \\
\hline & $2012-13$ & 3.0 & 0 \\
\hline & 2013-14 & 3.0 & 0 \\
\hline & $2014-15$ & 2.0 & -33.33 \\
\hline & $2015-16$ & 2.0 & 0 \\
\hline \multirow{5}{*}{ Number of Accidents } & $2011-12$ & 259 & 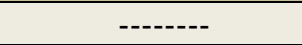 \\
\hline & $2012-13$ & 295 & 13.90 \\
\hline & 2013-14 & 241 & -18.31 \\
\hline & $2014-15$ & 249 & 3.32 \\
\hline & $2015-16$ & 263 & 5.62 \\
\hline \multirow{5}{*}{$\begin{array}{l}\text { Number of Fatal } \\
\text { Accidents }\end{array}$} & 2011-12 & 114 & ------ \\
\hline & $2012-13$ & 92 & -19.30 \\
\hline & 2013-14 & 91 & -1.09 \\
\hline & $2014-15$ & 116 & 27.47 \\
\hline & $2015-16$ & 123 & 6.03 \\
\hline \multirow{5}{*}{$\begin{array}{l}\text { Revenue Earning } \\
\text { kilometres (Lakhs) }\end{array}$} & $2011-12$ & $3,797.1$ & ------ \\
\hline & $2012-13$ & $4,225.8$ & 11.29 \\
\hline & 2013-14 & $4,213.2$ & -0.30 \\
\hline & $2014-15$ & $4,666.8$ & 10.77 \\
\hline & $2015-16$ & $4,589.28$ & -1.66 \\
\hline \multirow[t]{5}{*}{ Staff Strength (Number) } & 2011-12 & 16,610 & \\
\hline & $2012-13$ & 18,974 & 14.23 \\
\hline & $2013-14$ & 18,634 & -1.79 \\
\hline & 2014-15 & 18,259 & -2.01 \\
\hline & $2015-16$ & 17,646 & -3.36 \\
\hline \multirow{5}{*}{$\begin{array}{l}\text { Fuel Efficiency (km/litre } \\
\text { of HSD) }\end{array}$} & 2011-12 & 4.8 & $-\cdots---\cdot$ \\
\hline & $2012-13$ & 4.8 & 0.00 \\
\hline & $2013-14$ & 4.73 & -1.46 \\
\hline & $2014-15$ & 4.75 & 0.42 \\
\hline & $2015-16$ & 4.74 & -0.21 \\
\hline \multirow{5}{*}{$\begin{array}{l}\text { Passengers kilometres } \\
\text { carried (Lakhs) }\end{array}$} & $2011-12$ & 4,028 & ------ \\
\hline & 2012-13 & 4,527 & 12.39 \\
\hline & 2013-14 & 4,466 & -1.35 \\
\hline & 2014-15 & 4,683 & 4.86 \\
\hline & $2015-16$ & 4,554 & -2.75 \\
\hline \multirow{5}{*}{ Occupancy Ratio \% } & $2011-12$ & 74.0 & ------ \\
\hline & $2012-13$ & 79.0 & 6.76 \\
\hline & $2013-14$ & 71.9 & -8.99 \\
\hline & $2014-15$ & 74.3 & 3.34 \\
\hline & $2015-16$ & 75.29 & 1.33 \\
\hline \multirow{5}{*}{$\begin{array}{l}\text { Passengers carried per } \\
\text { Bus/ Day }\end{array}$} & 2011-12 & 323.5 & ------ \\
\hline & 2012-13 & 330.3 & 2.10 \\
\hline & $2013-14$ & 320.6 & -2.94 \\
\hline & 2014-15 & 314.6 & -1.87 \\
\hline & $2015-16$ & 298.41 & -5.15 \\
\hline
\end{tabular}




\begin{tabular}{|l|c|c|c|}
\hline \multirow{3}{*}{$\begin{array}{l}\text { Net Profit / Loss (Rs. } \\
\text { Lakh) }\end{array}$} & $2011-12$ & $(-) 21,593$ & ------- \\
\cline { 2 - 4 } & $2012-13$ & $(-) 28,481$ & 31.90 \\
\cline { 2 - 4 } & $2013-14$ & $(-) 40,680$ & 42.83 \\
\cline { 2 - 4 } & $2014-15$ & $(-) 59,781$ & 46.95 \\
\hline \multirow{3}{*}{$\begin{array}{l}\text { Net Profit / Loss per km. } \\
\text { (paise) }\end{array}$} & $2015-16$ & $(-) 57,717$ & -3.45 \\
\cline { 2 - 4 } & $2011-12$ & $(-) 568.70$ & ------- \\
\cline { 2 - 4 } & $2012-13$ & $(-) 673.99$ & 48.51 \\
\cline { 2 - 4 } & $2013-14$ & $(-) 965.53$ & 7.08 \\
\hline \multirow{3}{*}{$\begin{array}{l}\text { Net Profit / Loss per Bus/ } \\
\text { Day (Rs.) }\end{array}$} & $2014-15$ & $(-) 1,033.88$ & 21.68 \\
\cline { 2 - 4 } & $2015-16$ & $(-) 1,258$ & ------ \\
\cline { 2 - 4 } & $2011-12$ & $(-) 2,072.37$ & 19.50 \\
\cline { 2 - 4 } & $2012-13$ & $(-) 2,920.62$ & 40.93 \\
\cline { 2 - 4 } & $2013-14$ & $(-) 3,240.72$ & 10.96 \\
\hline
\end{tabular}

Source: Review of the performance of State road transport undertakings.

Data from table -2 reveals that in the year there were 3402vehicles in 2011-2012 which increased to 4170during the year 2014-15 which shows healthy sign. Whereas the life of vehicles is concerned it was 7.0 year in the year 2011-2012 which declined to 4.07 year. As a result the percentage of accidents also increased there were 259 in the year 2011-2012 increased 263to due to low quality vehicles. As regards Revenue earnings is concerned it was Rs. 3797.1 lakhs per kilometer in 2011-12 increased to Rs. 4589.28 in 2015-16 which shows ascending growth rate. But due to less income and more expenditure bear and tear overall profit portion declined. It was (-) 1,734.27 Net Profit / Loss per Bus/ Day (Rs.) in the year 2011-2012 which increased to (-)3,782 during the year 2015-2016 respectively shows an alarming sign to its employees and police makers. Human resources are considered as back bone of any organization. Due to faulty planning, recruitment of staff on contract basis after it has shown a declining trend it was 18,974 2012-13 decreased to 17,646 in the year 2015-2016.

\section{SUGGESTIONS}

1. The efficiency of public transport depends and influenced by many internal as well as external factors that could not be controlled by managers. The internal factors comprise personnel policies, pay and perk incentives etc. Internal factors can be controlled whereas external factors could be called environmental variables including competition, modes of management, customer regulations, contractual arrangement and subsidy schemes, interstate routes, and competitions etc. A depot manager has to control the affairs related to all types of buses included ordinary and deluxe while the working as management, EPKM, KMPL of both type of buses are different and varies depot to depot. Generally, ordinary buses run at local routes, in rural area with poor road conditions, frequent halts, and overcrowding have low KMPL, EPKM. In contrast the deluxe buses run on inter-state routes, highways with special features of bus service and earn more KMPL, EPKM relatively. At the time of evaluation and performance appraisal of depot manager this factor is not considered. The income of the depot also varies as per locations. Therefore it is suggested that nature of job and other factors should be taken in to consideration.

2. Although for excellent performance of drivers certificate of appreciation is given and no other financial benefits are given. Therefore to motivate the employees some financial benefits be given to maintain their morale

3. In the corporation there are two types of employee i.e. regular and contractual. The salary structure of regular is very high as compared to contractual. They get very less salary in comparison with regular for same type of job. Secondly there are more conductors than drivers. Due to lack of drivers conductors are given man days between 
20-25 days on an average in a month which demotivate them. Therefore it is suggested that rule of equal salary for equal work should by applicable.

4. Complaint facility to passengers is the part of service quality but in case of any complaint from passenger the priority is given to passengers only and generally hearing is not given to staff, it should be given to both parties. Because some time passengers misuse it.'

5. To deal with public some staff members lack proper language to deal with customers. Therefore it is suggested that behavioral school be opened in each depot and under outsourcing this facility be provided to each and every employee.

\section{CONCLUSION}

The economic growth of developing country like India mainly depends on the development of adequate, speedy, efficient and economic transport system. From the analysis of the observation made and problems identified it has been found that there are numbers factors responsible for the sad state of affairs in the corporation. Some of them are no doubt caused by external forces. But simultaneously it should focus on Worker's participation, incentive method, recreational facilities as yoga, sports for distress and some motivational lectures can be applied to increase the efficiency and productivity. In order to bridge the gap between demand and supply of transport services, it is necessary that passenger road transport undertaking should continue to be run with well-planned and efficient network.

\section{References:}

Mitra, S. Review of the Performance of State Road Transport Undertakings. Ministry of Road Transport and Highways. New Delhi.

Government of Haryana. Department of Economic and Statistical Analysis, Haryana. Economic Survey of Haryana, 2016-17.

Mahajan, V.S. 1991. Transport Planning Policy and Development. Deep \& Deep Publication, New Delhi.

Muehlen, M.Z. 2002. Workflow- based Process Controlling Foundation, Design, and Application of Workflowdriven Process Information System. ISBN 3-8325-0388-9. ISSN 1611-3101.

Kerzner, H. 2001. Project Management A System Approach to Planning, Scheduling and Controlling. John Wiley \& Sons, Inc., New York. Chichester. Weinheim. Brisbane. Singapore. Toronto.ISBN 0-471-39342-8.

Simons, R. 1995. Levers of Control How Managers Use Innovative Control System to Drive Strategic Renewal. Harvard Business School Press. Boston, Massachusetts. ISBN 0-87854-559-2.

Sisaye,S. 1951. The Ecology of Management Accounting and Control Systems Implications for Managing Teams and Work Groups in Complex Organizations. ISBN 1-56720-521-6.

Ghosh, N. 2005. Management Control System. Prentice Hall of India Private Limited. New Delhi. Retrived from www.google.co.in/books.

Anthony, R.N., Govindarajan, V. 2008. Management Control System. Tata Mc Graw Hill Publishing Company Limited, New Delhi. Retrived from www.google.co.in/books.

http://hartrans.gov.in 